\title{
Financial Engineering of Infrastructure Projects: The Concessional Mechanism
}

\footnotetext{
Submitted 04/01/19, 1st revision 19/02/19, 2nd rervision 23/03/19, accepted 05/05/19

Andreeva, L.Yu. ${ }^{1}$, Fedorov, A.V. ${ }^{2}$, Prokopenko, E.S. ${ }^{3}$, Sichev, R.A. ${ }^{4}$

Abstract:

Purpose: The article considers the model of financial engineering, in which financial resources for an infrastructure project are formed based on syndicated loans.

Design/Methodology/Approach: The study is based on modern concepts of uncertainty and risk management theories and the concept of digital economy. It includes a system and diagnostic analysis, methods of financial analytics as well as quantitative and qualitative risk assessment methods.

Findings: Authors analyzed the investment in the infrastructure projects development in the Russian Federation. The railways' export potential is analyzed and determined to depend on coal and container terminals. Authors highlighted the need for business consolidation and new infrastructure projects based on technologies of digitalization in the transport industry, reviewed the strategic importance of concession agreement for the construction of "Northern Latitudinal Railway".

Practical Implications: The research findings revealed that implementation of large infrastructure projects is capable to render breakthrough effect on GDP and economic growth rates of the Russian Federation. The adjusted experience could be introduced in the transport framework of the Russian Federation and abroad.

Originality/Value: The main contribution of this study is in the highlighting features of concessional mechanism in the framework of large infrastructure projects.
}

Keywords: Financial engineering, infrastructure projects, concessional mechanism, syndicated loans, financial resources.

JEL codes: G24, G28, L32, R40, R42.

Paper Type: Research article in Special Issue dedicated to Russian Economy.

Section 2: Banking \& Finance.

\footnotetext{
${ }^{1}$ Doctor of Science (Economics), Professor, Head, Department of "Economics and Finance", Rostov State Transport University, Rostov-on-Don, E-mail: andreevalarisa@mail.ru

${ }^{2}$ Ph.D., (Law), Dean of the Department of 'Economics, Management and Law"; Professor, Department of Administrative law and criminal and legal disciplines, Rostov State Transport University, Rostov-on-Don, E-mail: upip@kaf.rgups.ru

${ }^{3}$ Ph.D., (Economics), Associate Professor, Department of "Economics and management", Rostov State Transport University, Rostov-on-Don, E-mail: em@kaf.rgups.ru ${ }^{4}$ Ph.D., (Economics), Assistant Professor, Department of Audit, Rostov State University of Economics., Rostov-on-Don, E-mail: Sichevroman@gmail.com
} 


\section{Introduction}

Financial engineering allows uniting organizational and financial resources of the largest Russian banks (Sberbank, VTB, Gazprombank, VEB) to create an innovative model of project financing for the Northern Latitudinal Railway construction. This is a very attractive project for banks in terms of risk and return. Concession is an attractive mechanism for banks because the state covers the risk of loan default. If, during the design, the project's estimate increases by more than $10 \%$, then the investor will share this risk with the state, as well as the risk of natural force majeure; an investor is protected if there is not enough cargo to pay back the way. Financial engineering allows increasing the Russian railways' export potential by developing new schemes of finance and renovating existing ports and adjacent railway stations.

\section{Methodology}

The research has a theoretical basis, formed on modern concepts of uncertainty and risk management theories, and the concept of digital economy (Polyakova et al., 2019; Thalassinos \& Thalassinos, 2018). The research methodology, in addition to general scientific research methods, includes system and diagnostic analysis in line with functional approach, methods of financial analytics and quantitative and qualitative risk assessment methods.

\section{Features of Financial Management of Infrastructure Projects}

Investment in the infrastructure projects development in the Russian Federation demonstrates high growth dynamics. The largest investment is observed in the railway construction and airport infrastructure. Cost of projects for which concession agreements with investors were signed in 2018, were estimated by the InfraOne investment company at about 512 billion rubles. At the same time, compared to 2017, the volume of investment increased by 2.4 times. In 12 years, the state signed about 300 concession agreements for 1.4 trillion rubles. Therefore, in 2018 investment in the infrastructure projects development increased almost by 2 times. The construction and reconstruction of the Sheremetyevo airport infrastructure cost 61 billion rubles, the modernization of the airport in Novy Urengoy cost 7.2 billion rubles. An investor was the Urengoyaeroinvest Corporation, which is a part of the Airports of Regions holding of the Renova Group. Currently, the number of road projects has decreased. In 2018 a concession agreement for 30 billion rubles was signed for the construction of a highway in the Moscow region (Krasnushkina, 2019)

In 2019 the state plans to invest more than 2.2 trillion rubles in the infrastructure projects. From January 1, 2019 the largest projects will be implemented under the Comprehensive plan for the modernization and expansion of trunk infrastructure. A development fund created in the federal budget will function as an organizational 
and financial mechanism for the infrastructure projects implementation, while about $50 \%$ of the fund will be used to finance the infrastructure. In the federal budget the main increase in costs on infrastructure will occur in 2019, the analysts of the Russian Presidential Academy of National Economy and Public Administration and the Gaidar Institute stated the conclusion for the three-year budget estimate, mainly due to an increase in costs on communications and information technology, as well as on road facilities.

Table 1. Terms of Infrastructure Projects Financing

\begin{tabular}{|c|c|c|c|c|c|c|}
\hline & \multicolumn{2}{|l|}{ 2010-2014 } & \multicolumn{2}{|l|}{2017} & \multicolumn{2}{|l|}{2018} \\
\hline & $\begin{array}{l}\text { starting } \\
\text { conditions }\end{array}$ & $\begin{array}{l}\text { end } \\
\text { conditions }\end{array}$ & $\begin{array}{l}\text { starting } \\
\text { conditions }\end{array}$ & $\begin{array}{l}\text { end } \\
\text { conditions }\end{array}$ & $\begin{array}{l}\text { starting } \\
\text { conditions }\end{array}$ & $\begin{array}{l}\text { end } \\
\text { conditions }\end{array}$ \\
\hline $\begin{array}{l}\text { return on } \\
\text { private } \\
\text { equity } \\
\text { (on own } \\
\text { equity of } \\
\text { investors) }\end{array}$ & $12-15$ & $\begin{array}{l}18-25 \\
\text { and } \\
\text { higher }\end{array}$ & $10,1-12,1$ & $10,6-12,8$ & $10,9-15$ & $11-15,5$ \\
\hline $\begin{array}{l}\text { interest rate } \\
\text { on principal } \\
\text { (in rubles by } \\
\text { a medium- } \\
\text { term credit) }\end{array}$ & $8-10$ & $12-13$ & $8,75-12$ & $9,75-12,9$ & $9,5-10,6$ & $9,5-11$ \\
\hline $\begin{array}{l}\text { various } \\
\text { commissions } \\
\text { by a credit } \\
\text { (hidden and } \\
\text { explicit) }\end{array}$ & $0,5-1$ & $1,5-2$ & $0,5-1$ & $0,84-1,96$ & $0,5-1$ & $1-1,56$ \\
\hline
\end{tabular}

Investors' profitability in most infrastructure projects shows good dynamics: in 2018 the growth in their income was about $15-15.5 \%$ against $10.6-12.8 \%$ in 2017 . At the same time, the investors' profitability growth rate has not yet reached the precrisis level of $18-25 \%$ in 2014. In 2018 the rates of debt financing lowered, for example, maximum rates were about $11 \%$ per annum compared to $12.9 \%$ in 2017 .

According to the experts, in 2019 a concession will be signed for the Taman port project (more than 232 billion rubles), a weight and dimensional control system (about 118 billion). A project to build a bridge over the Lena River, regional road and new passenger transport projects are planned, as well as railway and airport concessions (Shklyaruk, 2019).

In addition to the railway plan, the budget estimate also provides another infrastructure financing, for example, the highways renovation under the Safe and High-Quality Highways program (1.2 trillion rubles). The projects are to be financed from the development fund, which is created within the budget: 1.5 trillion rubles 
are provided for capital construction and the infrastructure creation (Federal State Statistics Service, 2018).

Figure 2. Concessions Market Dynamics

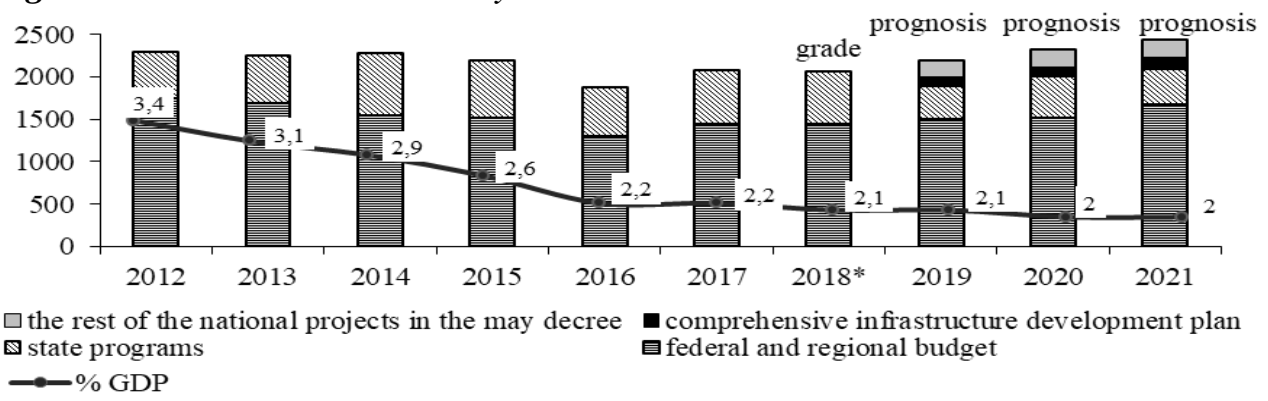

Note: * The calculation of infrastructure investments in monetary done made on the monthly reports of the Federal Treasury, the final grade will appear in May 2019.

Population life quality will be most influenced by regional roads renovation, airports reconstruction and aviation routes decentralization. The projects of the Moscow Kazan high-speed railway and Europe - Western China way as well as acceleration of container trains in conjunction with the creation of transport and logistic hubs will contribute to the economy growth. These projects will increase transport accessibility from Russian regions to global markets.

According to the passport of the Moscow - Kazan high-speed railway federal project, this is a project of regional development of seven regions, and the main budget expenses will start from 2022. According to the PwC experts, a kilometer of the Moscow - Kazan railway will be almost 2 times cheaper than a kilometer of the Seoul - Beijing or Cologne - Frankfurt way (Andreeva and Shevchik, 2018). The state will share the risk of passenger traffic reduction with the concessionaire in the proportion of 80 to 20 . In 20182.3 million passengers were transported by trains in the area where a high-speed rail line will pass. The financial model will bear a $10 \%$ increase in expenses and a 30\% drop in traffic (Skorlygina, 2018).

Construction of high-speed railways for the Russian Federation will make a technological breakthrough, but in the implementation of this model a lot depends on traffic. It is important not to develop competing flights, new highways on the route, but to invest in the development of territories. There should be reasonable tariffs so that the population could afford using this type of transport.

One of the peculiarities of the Russian high-speed railway projects implementation is that these projects are rather cost-intensive and do not pay off by selling tickets. The corporation seeks to attract Chinese and European investors to finance highspeed railway projects. The German Initiative Partnership is ready to provide active support to the Russian Railways Corporation in the creation of the Moscow - Kazan 
route, including in matters of finance. Deutsche Bahn, Strabag, Vossloh, Rail.one, Kapsch and others participate in this partnership in addition to Siemens. However, the schemes of finance for many infrastructure projects are just being formed. In difficult economic conditions for Russia, the construction of high-speed railways can be economically feasible only based on a combination of several factors. In terms of freight traffic, the effect will be ambiguous, since Sapsan is quite enough for cargo and parcels, and the construction of a high-speed line will be cost-effective and have a long payback period (at least 40 years).

\section{The Railways Export Potential Depends on Coal and Container Terminals}

The railways export potential has been doubled over the past 10 years due to opened new seaports and modernization of existing ones and adjacent railway stations. Over the past decade, cargo turnover of Russian ports has grown by almost $80 \%$, and capacity has exceeded 1 billion tons per year, according to the data from Freight One, the largest private railway operator in Russia. Recently, coal and container terminals, terminals for transshipment of mineral fertilizers have been developing actively. In the ports of the Baltic Sea and the Azov-Black Sea coast there is a shortage of grain terminals, and in the Far Eastern and Arctic basins there is a shortage of coal terminals. To meet the demand, additional coal terminals will be opened in the Far East soon. Taman port is developing on the Black Sea, and Lavna port on the Barents Sea. By 2024, transshipment volumes in ports are projected to grow by another 350 million tons per year, and freight turnover will increase by $33 \%$ (Skorlygina, 2018).

\section{The Need for Business Consolidation}

The railway industry reform has led to the emergence of numerous private operators owing railway cars. Currently, about $90 \%$ of freight traffic is formed by independent companies. Financial stability of the rail transportation market, despite high rates, is quite low. If market participants do not consolidate business, then government regulation may return. The larger the company is, the more technological it is, and it is easier to optimize logistics and manage the park. The railway market has suffered the periods of park surplus and deficit, as well as a period of high volatility of the railway car's profitability.

According to the expert estimates, the Russian Railways Corporation plans to invest funds from the Trans container future sale in infrastructure provision to increase container transit by 4 times. According to the experts of the holding, it will take 100150 billion rubles, and another 200-300 billion rubles should be invested in the park of platforms and containers (Skorlygina, 2019). In fact, it is said about the purchase of at least equivalent of two Trans container parks. However, the transit situation is such that high rates contribute to the growth of the park (Figure 3). 
In order to attract investment resources, the Russian Railways Corporation has increased the volume of the bond placement program to 350 billion rubles from 150 billion rubles to finance the long-term company's development program until 2025.

Figure 3. Container transportation by the Russian Railways

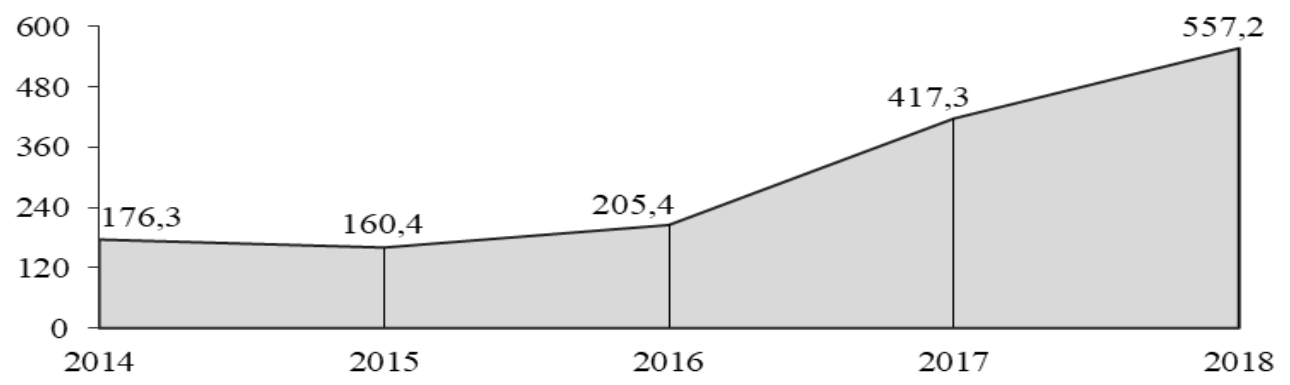

In autumn 2016 the Russian Railways Board of Directors approved a bond program for up to 150 billion rubles or equivalent of this amount in foreign currency. The corporation has published a message about changes in the program of exchange bonds and their leaflet. It is a program of exchange bonds of 001P series. The maximum bonds' maturity period is up to 40 years. The program has been declared as unlimited in time and the bonds will be placed as needed. The long-term Russian Railways program until 2025 provides for a volume of investment in railway infrastructure of about 10 trillion rubles, of which more than 7 trillion rubles will be invested by the company itself; the rest should be private investors' funds (Vestifinance, 2018).

\section{Analysis and Assessment of Infrastructure Projects}

The research of the latest experience of development of infrastructure of the real sector of the economy showed that the largest projects (considering volumes of investment) develop based on the mechanism of the public-private partnership (PPP). Most often forms of PPP of interaction are applied in the transport sphere: in road construction such projects appeared long ago, and in the railway began to be implemented three years ago therefore the relevance of instruments of financial controlling increases in ensuring sustainable development of the companies. Due to high capital intensity the few investors are capable to take part in large infrastructure projects (Andreeva and Andreeva, 2017). New infrastructure projects based on technologies of digitalization in the transport industry are difficult and technologically high considering specifics of transportation process on railway transport and the technologies of management of infrastructure.

Financial controlling is required because due to limited investment in transport projects, the complexity of risk management has increased compared to other concessions. It is also important to note that many Russian shippers are the companies engaged in mining or manufacturing, and with rare exceptions, it is 
difficult for them to participate in the development of non-core business, i.e., in infrastructure projects.

Therefore, today railway concessions can develop in no other way than in the alliance of the Russian Railways holding and independent investors who are directly interested in the infrastructure projects. The Russian Railways Corporation is the only full-cycle company on the Russian rail market. Risks are also increasing because independent investors are not fully on top of the issues of the infrastructure operation and its financial management. In this regard, the Russian Railways Corporation should become an active participant in the projects based on public and private partnership, using practical and applied tools of financial controlling.

Construction of the Northern Latitudinal Railway (NLR), in which the concessionaire is not related with the traffic generators, but provides services to the rail transport market, can be considered as the first market railway concession. The concessionaire is planned to be responsible for the road operating until 2052. Construction should be completed in 2022; the projected transportation volume is 23.9 million tons of oil products and gas condensate per year (Chernigovsky, 2018).

This option of the concession can be a model for future projects. The Russian Federation Government and private investors sought to develop an optimal concession model and optimize the risk of traffic management model. The risk of traffic is a key risk for transportation projects. The concessionaire's income depends on the traffic. An investor cannot fully assume the risk management, since the probability of this risk realization depends on many factors, including macroeconomic ones, as well as on the efficiency of the infrastructure operation. The state is also not interested in being responsible for managing the risks of traffic, even though it is this condition that banks and investors insist on.

In such a model, the state pays to the concessionaire the minimum guaranteed income; the difference between real concessionaire's incomes and the incomes that are embedded in the financial model to ensure debt service, operating costs and return on equity. A compromise solution, when private sector could take part of the key risk, was found for the Northern Latitudinal Railway project implementation. It was not reasonable to reduce the concessionaire's income by the amount related to the debt servicing, since in this case such a model could limit the loan financing of the project. It was also impossible to reduce its costs associated with the infrastructure maintenance, because in this case the risks of keeping the object of the concession appear. However, the use of financial controlling tools will allow managing the project's profitability. For example, if cargo traffic becomes lower than planned, the state covers most of the concessionaire's costs, except return on equity. In this case, the investor acquires direct economic interest in the organizational and financial control of the project in order to obtain return on equity. With this option, the state as the sole shareholder assumes responsibility for the actions of the Russian Railways holding, as well as admits the concessionaire's right 
to have market return and guarantees him fair compensation in case of early termination of the concession.

\section{Elaboration of the Development Plan for the Main Infrastructure}

The Russian Federation Government has approved a plan for the long-distance infrastructure development, which should ensure the economic coherence of the territories. The plan of the long-distance infrastructure includes objects of transport and energy infrastructure. The cost of the transport part of the plan is 6.3 trillion rubles, 3 trillion of which will be provided by the federal budget, and the remaining financial resources will be attracted from non-budgetary sources. Significant amounts of funding will be directed to the construction and reconstruction of the roads in the Europe - Western China transport corridor. 655 billion rubles of investments are provided for this direction, including 390 billion rubles are planned to be allocated from the federal budget. The development of long-distance infrastructure will allow Russian transport companies increasing export of services. For example, it is planned that the number of transit traffic will increase by $35 \%$, the period of transit from the western border to the Far Eastern ports will shorten from nine days to seven, freight traffic along the Northern Sea Route will be activated, and $301 \mathrm{~km}$ of high-speed ways will be commissioned in 2024 (Adamchuk, 2018).

Elaboration of a long-distance infrastructure development plan will increase attractiveness of the projects for private investors. Currently, very few Russian companies and investment funds have long-term plan resources. This is due to the realization of financial risks and increase of uncertainty in the economy. Infrastructure operators of the market should be interested in the long-term stability of the economy of projects, and not just in obtaining profit. In this regard, economic incentives for the development of such projects and state support are required.

It should be noted that assessing the quality of the pledge, the Bank of Russia does not equate the pledge of rights under a concession to the state guarantee, even though the government undertakes to repay the loan to the bank under a concession agreement. The infrastructure programs development is slowed by the preparation of project documentation, which elaboration takes a lot of time. In order to increase the number of infrastructure projects, the Vnesheconombank (VEB) aims to enhance the attraction of investment in the economy through the mechanism of syndicated lending. VEB will implement this mechanism together with other Russian commercial banks. Syndicated lending allows reducing the cost of attracted resources and increasing the number of projects.

So far, VEB has acted as the sole lender in projects, and the share of syndicated lending was less than $10 \%$. This is a very low level of interaction with Russian commercial banks, which limits the potential of the development institution. As a support for the participation in the projects, VEB will receive 300 billion rubles from 
the National Wealth Fund (NWF) for additional capitalization. VEB wants to stimulate investment growth in a strategic partnership with commercial banks.

Currently, VEB has developed and implemented most of the investment projects with three largest state-owned banks: Sberbank, Gazprombank, and VTB. The plan for the long-distance infrastructure development, approved by the government, implies an increase in the number of banks involved in supporting investment projects. It should be noted that more than 10 Russian credit organizations have signed the agreement of intent to participate in syndicates with VEB. Currently VEB is developing the "Factory of Project Finance", a new institute allowing project participants receiving tranches to pay interest at the investment phase.

\section{The Concession Agreement of the "Northern Latitudinal Railway"}

At the end of September 2018, a concession agreement for the construction of "Northern Latitudinal Railway" was signed between Roszheldor and the SSH company, specially created for the project. The project includes the construction of the bridge across the $\mathrm{Ob}$ with railway accesses, the Salekhard-Nadym railway line, and the bridge across the Nadym. The concessionaire will have to provide finance, construction and operation of the Obskaya - Salekhard - Nadym line. The total length of the road under the concession is $353 \mathrm{~km}$, and its total cost is 113 billion rubles 50 billion rubles of which will be allocated to the construction of the bridge, 61 billion rubles for the construction of the railway line and about 2 billion rubles for construction works across Nadym. The experts estimate the total cost of the project, considering construction and reconstruction of the adjacent areas at 236.7 billion rubles. This project meets the market concession model. At the same time, the formats of the newly created infrastructure offered by the concessionaire will be in demand by the carrier and shippers. The concessional part of the project will amount to 12.7 billion rubles in the form of a capital grant, loan finance will amount to about 97.2 billion rubles, and corporate investment finance should be 18.4 billion rubles. The shareholders of the project plan to make capital investments of 1.8 billion rubles (Adamchuk, 2018).

It was decided that in case of increase in the project's estimate by more than $10 \%$ of the original amount, the state would take financial responsibility for the growth of expenses in equal shares with the investor. In the early stages of the project implementation, the state will maintain financial stability of the investor in case the flow of transit for the payback of the project will be limited.

The importance of the project for reducing the length of transport routes from fields in Western Siberia to the ports of the Baltic, White and Barents seas is difficult to estimate. The project "Northern Latitudinal Railway" combines a set of geopolitical advantages related with the development of northern territories and allows optimizing time and distance of transportation of several raw materials for export. The route through the Arctic, which is opened for regular shipping due to melting 
ice, is shorter than the traditional route through the Suez Canal, but cannot yet be its full alternative. The project will ensure the integration of the Northern and Sverdlovsk railways, reduce the transport arm for the shippers of the Urals Federal District, and allow releasing partially the Transsib facilities. The project "Northern Latitudinal Railway" should play a strategic role in the program for the development of transport infrastructure of the Yamalo-Nenets Autonomous District and the Arctic zone of the Russian Federation.

The project "Northern Latitudinal Railway" has a great strategic potential, since container ships transport is approximately $98 \%$ of the world's consumer goods. Ships able to hold about 20 thousand standard containers are used for trade between Europe and Asia. Even though the Northern Sea Route is much shorter, but it would be more expensive for freight carriers, since only relatively small container ships accompanied by nuclear icebreakers can go through it. The risks and limitations in the project implementation consist also in the fact that in case of an emergency in the Arctic, it is difficult to evacuate the crew of the ships and eliminate the oil spill.

The Russian Federation exports liquefied natural gas (LNG) along this route to Europe. In July 2018, the Novatek delivered gas from Yamal LNG to China for the first time. Russia relies on the development of transport links along the Northern Sea Route. At the Eastern Economic Forum, President Vladimir Putin said that the Far East should become a powerful economic industrial center with great potential (Vovchenko and Andreeva, 2017). Modernization and development of transport infrastructure, including along the route through the Arctic, will strengthen the coherence of the Asia-Pacific region and Europe.

\section{The Mechanism for Syndicated Crediting}

The mechanism of interaction between commercial banks and VEB is formed based on risk transfer. For example, VEB plans to take financial risks associated with market conditions, price cycling, inflation, and cost overruns. When implementing organizational and financial risks, in order to keep the stability of credit institutions being participants of the projects, VEB will allow other lenders being the first to receive money in case of bankruptcy. Implementation of a new mechanism of work with banks also provides participation of the development institution in ensuring the financial stability of partner banks. Thus, VEB admits the possibility to join the problem of debt servicing, for example, to assist the borrowing bank in paying interest, so that banks participating in the project do not have to establish additional reserves. It is also important to note that VEB can also use a new tool, namely, to provide guarantees for the loan to the project participants.

Sanctions have closed Western markets for Russian banks. Due to the circumstances, the main source of funding for the development institution is bonds. Recently VEB have issued mainly short-term bonds, and the income on 10-year issues was $8-9 \%$. In order to lower the rate and attract actively commercial banks to 
syndicates, VEB is discussing the issue of providing subsidies with the Ministry of Finance. The number of subsidies will depend on the number and cost of projects. As a development institution, VEB can attract financial resources at prices that are lower than the market ones. This will be interesting for the partner banks, since a lower debt burden on the project reduces the risks of credit institutions.

It can be assumed that funds from the National Wealth Fund (NWF) will be provided not for additional capitalization, but as a deposit on more favorable terms than the prevailing market conditions. VEB will finance the approved projects in 2020-2021, now they are just preparing. VEB will carry out the organizational and financial adaptation of projects independently, and then will transfer the project based on the mechanism of syndicated lending to the market, providing financing of $10-40 \%$. To reduce the risks of implementing infrastructure projects, the government suggests changing the mechanism for additional capitalization of development institutions. This mechanism involves the provision by the bank of not financial resources, but a subscribed capital. The subscribed capital will be provided as the need for investment resources arises. The subscribed capital will appear for Vnesheconombank (VEB), the Russian Export Center and the Small and Mediumsize Business Corporation. Changes are required for the rapid provision of subsidies.

The Auditing Chamber of the Russian Federation points out the weak points found in the current mechanism of spending financial resources that state companies and state corporations receive through subsidies. According to the auditors' conclusion for the budget performance report, at the beginning of 2018, the Auditing Chamber found 155 billion rubles of such free funds; this is by 15 billion rubles more than by early 2017. The auditors are also dissatisfied with the income from their investment of resources, 7 billion rubles in 2017 (Kholyavko, 2018). When allocating budget funds, financial coordinators do not always consider readiness of the projects, real needs in money, and the possibility of their use. The subscribed capital is not so much the money itself, but the guarantees that it will be received if required. It is important that the lag between the emergence of the need and the provision of money does not exceed a year otherwise, investors will lose interest in strategic projects.

\section{Conclusions and Recommendations}

Implementation of large infrastructure projects is capable to render breakthrough effect on GDP and economic growth rates of the Russian Federation. The stimulating factors of implementation of the large infrastructure project are the following:

- Growing volumes of trade in goods with high added value, sensitive to the time of delivery;

- Growth of the online trade, including between China and the EU. The expected growth of retail online trade will be up to 4 trillion dollars in 2020; 
- Processes of the urbanization and globalization and the growth of the population mobility in Russia and in the world; until 2050, the experts predict an increase in the total passenger traffic, including air transportation both within the Russian Federation and the CIS countries, and in intercontinental Eurasian traffic;

- Successful Russian projects for the construction of high-speed railways and highspeed transport in the European Union and China.

The Russian Railways corporation models a project finance portfolio based on a possible package of domestic state and international support measures, participation of available development institutions, including concessions, infrastructure mortgage, and other sources.

\section{References:}

Adamchuk, O. 2018. The Government Approved Development Plan for the Main Infrastructure. Vedomosti Newspaper from October, 11. URL: https://www.vedomosti.ru/economics/articles/2018/10/11/783488-net.

Adamchuk, O., Shtanov, V. 2018. Northern Latitudinal Railway is signed. Vedomosti Newspaper from October, 2. URL: https://www.vedomosti.ru/economics/articles/2018/10/02/782628-severnii-hod.

Andreeva, L., Andreeva A. 2017. Instruments of Marketing and Credit Support of the Large Industrial Enterprises Development: International Experience. European Research Studies Journal, 20, 1, 294-310.

Andreeva, O., Shevchik, E. 2018. Adaptive Risk-oriented Organizational and Financial Modeling in Ensuring Economic Systems Sustainable Development. The Journal of Science and Education: Economy; Entrepreneurship; Law and Management, 1(92), 14-17.

Chernigovsky, M. 2018. Where to Find 4 Trillion Rubles for Infrastructure Projects. The State Finally Managed to Agree with the Investor on the Concession Market Model. Vedomosti Newspaper from August, 28. URL: https://www.vedomosti.ru/economics/blogs/2018/08/29/779331-gosudarstvu-4-trlninfrastrukturnie.

Federal State Statistics Service. 2018. Consumer expectations in Russia of 2018. URL: http://www.gks.ru/bgd/free/b04 03/Isswww.exe/Stg/d02/66.htm.

Kholyavko, A. 2018. The Government will Toughen Control of Financing of State Corporations. Vedomosti Newspaper from November, 6. URL: https://www.vedomosti.ru/economics/articles/2018/11/06/785711-pravitelstvouzhestochit-kontrol-za-finansirovaniem-goskorporatsii.

Krasnushkina, N. 2019. There will not be Enough Projects for Infrastructure Money: Investment Monitoring. Kommersant Daily Newspaper, Issue 10, from January 22. P. 2. URL: https://www.kommersant.ru/doc/3860154?query=InfraOne.

Polyakova, A.G., Loginov, M.P., Serebrennikova, A.I. \& Thalassinos, E.I. 2019. Design of a socio-economic processes monitoring system based on network analysis and big data. International Journal of Economics \& Business Administration, 7(1), 130-139.

Shklyaruk, M. 2019. There is no more Government Administration without a Digit. Kommersant Daily Newspaper. Issue \# 36 from February 28, URL: https://www.kommersant.ru/doc/3896046. 
Skorlygina N. 2019. Russian Railways will Leave the Containers to the Market: Monopoly will Invest Funds from the Sale of Trans-container into the infrastructure.

Kommersant Daily Newspaper, Issue 19 from February 4, URL: https://www.kommersant.ru/doc/3873288.

Skorlygina, N. 2018. Railways will go According to Decrees: Russian Railways has Updated the Long-term Development Program. Kommersant Daily Newspaper, Issue 105, from June 20, URL:

https://www.kommersant.ru/doc/3662606?query=\%D0\%A0\%D0\%96\%D0\%94.

Thalassinos, I.E., Thalassinos, Y. 2018. Financial Crises and e-Commerce: How Are They Related. Available at SSRN: https://ssrn.com/abstract=3330169

Vestifinance. 2018. Russian Railways Increased the Bonds Placement Program to 350 billion rubles. The source of vestifinance.ru from August 7, https://www.vestifinance.ru/articles/104975 (Accessed: 12, January. 2019).

Vovchenko, N., Andreeva A. 2017. Competitive Advantages of Financial Transactions on the Basis of the Blockchain Technology in Digital Economy. European Research Studies Journal, 20(3B), 193-212. 